\title{
The effect of chronic dietary protein-calorie deficiency on reproductive performance of rats: respiratory metabolism of ova
}

\author{
By B. S. PLATT, IRENE M. BARRETT AND BARBARA A. CHRISTIE \\ Department of Human Nutrition, London School of Hygiene \\ and Tropical Medicine, Keppel Street, WC I \\ (Received I4 August 1968-Accepted 17 October 1968)
}

\begin{abstract}
I. The respiration rate of ova during their early cleavage stage from two groups of rats reared on diets of NDpCal \% ro or NDpCal \% 5 has been measured, using a Cartesian diver.

2. Measurements from twenty-six experiments show that the average oxygen uptake of ova from the rats reared on the diet of high protein value was $0.563 \pm 0.175 \mathrm{~m} \mu \mathrm{l} \mathrm{O} / \mathrm{ovum}$ per $\mathrm{h}$ and the value for rats reared on the diet of low protein value was $0.440 \pm 0.076 \mathrm{~m} \mu 1$ $\mathrm{O}_{2}$ /ovum per $\mathrm{h}$ when measurements were made in a medium containing $0.9 \% \mathrm{NaCl}$ and rat serum or plasma $(2: 1)$. The difference between these results was significant at $0.05>P>0.02$.

3. It is suggested that the lower respiration rate of ova from rats maintained on the diet of low protein value may be due partly to the effect of dietary protein deficiency on conditions within the Fallopian tube and partly to the effect on the maturation of the ovum itself.
\end{abstract}

Rats which are reared on a diet of low protein value have a poorer reproductive performance than rats reared on a diet of normal protein value; the number of eggs shed is reduced and prenatal mortality increased (Gupta \& Lacy, I967; Gupta \& Christie, 1968).

A mild protein-calorie deficiency from weaning is known to retard growth and has been shown to delay sexual maturity (Asdell \& Crowell, 1935) and cause uterine atrophy and ovarian degeneration (Bertók, Penzes \& Szeky, 1962).

Nelson \& Evans (I953) studied the relation of dietary protein levels to pregnancy in rats and found that $5 \%$ protein fed from the day of mating was the critical level below which reproduction was severely affected. At this dietary protein level resorption of embryos rose to $30 \%$, average maternal weight gain was small and the weight of the young at birth was below average. They found, by varying the time at which the rats were subjected to a deficiency of protein, that the critical need for protein was during the earliest stages of placental and foetal development. When a protein deficiency was not instituted until shortly after implantation, pregnancy was successful.

Harper (1964) found that approximately half of the pre-implantation loss of embryos in rats which were adequately fed was due to failure of development to the blastocyst stage.

Hartman (1953) considered that degeneration of ova during their cleavage stages may be attributed to defects in the egg, whilst Austin (I96I) suggested that in immature animals the conditions within the genital tract may be unsuitable for development of ova.

As an indication of the metabolic state of ova, it was decided in the present study to measure respiration rate (oxygen uptake) of ova during their early cleavage stage, 
immediately after removal from the Fallopian tube. The respiration rate of rat ova from healthy rats has been measured by Boell $\&$ Nicholas (1948), using a Cartesian diver at $37.5^{\circ}$, and also by Sugawara \& Umezu (1960, 196r).

The present series of experiments was designed to determine whether the protein value of the diet of a female rat had any influence on the metabolic state of fertilized ova. This has been investigated by measuring the respiration rate of ova at $37^{\circ}$, using a Cartesian diver.

\section{EXPERIMENTAL}

\section{Animals}

Female Wistar rats (black and white hooded strain) were obtained from the National Institute for Medical Research at weaning (approximately 25 days old), when they weighed $35 \pm 5 \mathrm{~g}$. They were randomly assigned to two dietary treatments (protein values NDpCal\% Io and NDpCal\% 5) (Platt \& Miller, r959; Platt, Miller \& Payne, I96I). (The term NDpCal \%, or net dietary-protein calories per cent, is a means of expressing the protein available for anabolic purposes as a percentage of the total calories of the diet (Platt \& Stewart, 1962).) The rats were housed in wire cages in a room maintained at $25^{\circ}-28^{\circ}$ and allowed free access to both food and water.

When a rat had attained at least $140 \mathrm{~g}$ she was paired with an adult male rat which had been reared on a stock diet of high protein value. Rats given a diet of protein value NDpCal \% ro at weaning take a further 40 days approximately to reach $140 \mathrm{~g}$, whilst those fed the diet of lower protein value (NDpCal \% 5) take about 80 days.

The morning when a mating plug was found was designated the ist day of pregnancy. Rats were then killed on day 2, 3 or 4 of pregnancy and their ova were used for experiment.

\section{Diets}

The composition of the diet of lower protein value was as follows: casein $4 \%$, maize starch $2 \mathrm{I} \%$ and basic diet $75 \%$. The basic diet consisted of thin-flake oats 45 parts, salt mixture (Jones \& Foster, I 942) 4 parts, vitamin B mixture in maize starch (Miller \& Bender, I955) I part, and beef dripping 25 parts by weight. The diet of higher protein value was prepared by replacing with casein $\mathrm{I} 8 \mathrm{~g}$ maize starch in each $100 \mathrm{~g}$ diet. In addition, each rat was given orally, once per week, $0.1 \mathrm{ml}$ arachis oil containing 250 i.u. of vitamin $A, 20$ i.u. of vitamin $D_{2}, 3 \mathrm{mg}$ of $\alpha$-tocopheryl acetate and $0.1 \mathrm{mg}$ of menaphthone.

\section{Diver apparatus}

Oxygen uptake measurements were made with the Cartesian diver apparatus as described by Holter (1943), using, in the early experiments, cylindrical divers whose volumes were about $20 \mu \mathrm{l}$. In later experiments, in an attempt to increase the sensitivity of the apparatus, similar divers of about io $\mu \mathrm{l}$ volume were used. The manometric fluid used was Brodie's solution. 
The technique described by Holter (1943, I96I) was followed with some modifications:

(I) The water bath was maintained at $37^{\circ} \pm 0.0 r^{\circ}$ by means of fish-tank heaters controlled by an electronic temperature regulator (Tempest, I963). When measurements are made with divers at $37^{\circ}$ and they are filled at room temperature, it is necessary to make certain adjustments in the position of the mouth seal. The calculations made by Waterlow \& Borrow (1949) have been applied in the present experiments.

(2) An illuminated stand was used for pipettes, which were drawn out from precision bore capillary tubing having an internal diameter $0.3 \mathrm{~mm}$, and scales were attached for measurement. One braking pipette was used to place the mouth seal and it was found convenient to place the pipette containing oil horizontally.

(3) The divers were cleaned carefully by washing in chromic acid, followed by water, acetone, toluene, and acetone, and were then coated with silicone, as described by Schwartz (1949) and Waterlow \& Borrow (1949), in order to produce a satisfactory water-repellent surface. The divers were filled with a solution of silicone in carbontetrachloride ('silicone repelcote') and left at $100^{\circ}$ overnight. Just before use the divers were washed with water, acetone, a little toluene, acetone again and then dried.

Divers were made and calibrated as described by Holter (1943, I96I) and 'diver constants' calculated.

\section{Media}

In an attempt to find the most suitable medium for the study of the respiration of ova, the medium used by Brinster (1965) for the study of the in vitro development of embryos of mice was used as a basis. In all, four different media containing a basic

Table I. Composition of media

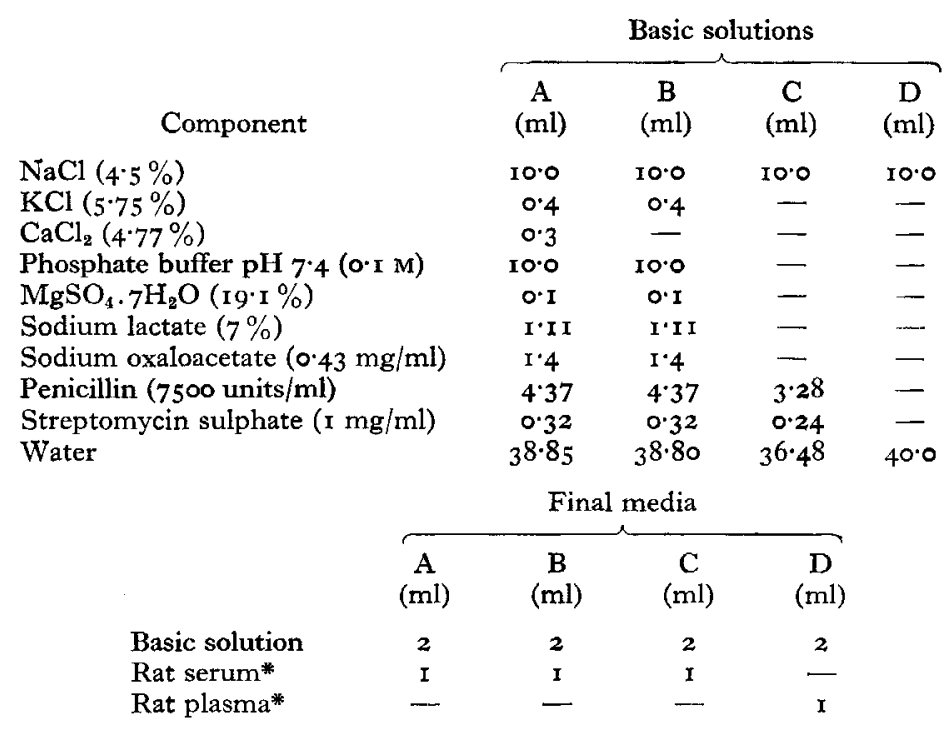

\footnotetext{
* Serum or plasma used to prepare media was obtained from rats in the same dietary group as the experimental animals.
} 
salt solution and either serum or plasma were used, as shown in Table I. Serum or plasma protein, obtained from rats on the same diet as the animal from which the ova were taken (see p. I88), was included in all media because a source of fixednitrogen had been found by Brinster ( 1965 ) to be necessary, both to prevent ova from sticking to glass surfaces, and as a source of amino acids. Medium A, the composition of which closely followed that of Brinster's medium, was tried first; also a modification, medium $B$ (see Table $\mathbf{I}$ ). The results obtained with these media showed on average a higher $\mathrm{O}_{2}$ uptake for the eggs from rats on the high-protein diet than on the low-protein diet, but were very variable (mean value $0.617 \pm 0.209$ for ova from rats fed on the diet of NDpCal $\%$ IO and $0.405 \pm 0.165$ for ova from animals fed on the diet of lower protein value).

As Boell \& Nicholas (1948) successfully measured oxygen uptake of rat eggs in physiological saline, it was subsequently decided to use a simple medium containing $0.9 \%$ sodium chloride and plasma in the ratio $2: \mathrm{x}$. This was used for both media $\mathrm{C}$ and $\mathrm{D}$; medium $\mathrm{C}$ was the same as $\mathrm{D}$ but with added antibiotics.

\section{Day of experiment}

On the chosen day of pregnancy (2nd, $3^{\text {rd }}$ or $4^{\text {th }}$ ), the rat was killed by means of ether vapour. Blood was removed from the heart for the preparation of plasma or serum for use in future experiments.

The ovaries and Fallopian tubes surrounded by fat were then removed and placed on a microscope slide. An attempt was made, as suggested by Austin (1961), to wash out the ova by passing medium through the Fallopian tube by means of a fine glass pipette, but this was found technically difficult. The following method of obtaining the ova was then tried and found satisfactory. The Fallopian tube was first dissected and placed in a covered cavity dish containing a few drops of prepared medium. With the aid of a dissection-microscope, it was then cut into many small pieces in order to liberate the ova. Small portions of medium and tissue were transferred with a pipette to a microscope slide and examined $\left(x_{100}\right)$. When an ovum was found it was put into a covered collection slide in a drop of medium.

The equipment with which the eggs and medium came into contact was sterilized either by heating in an oven at $165^{\circ}$ for $2.5 \mathrm{~h}$, or in an autoclave at $15 \mathrm{lb}$ pressure for I 5 min. The media were sterilized by passing them through a compressed paper disk, using a Seitz filter.

When sufficient ova (between four and twenty-one) (see Table 2) had been gathered together from either one or two rats, the ova were transferred to a cavity slide in a drop of medium. The density of the ova, being greater than that of the medium, causes them to fall close together at the bottom of the depression. They can then be collected in a very small quantity of medium $(0.68 \mu \mathrm{l})$ and, by means of a fine calibrated pipette, transferred to an equal quantity of medium which forms a band in the Cartesian diver (Fig. I). 


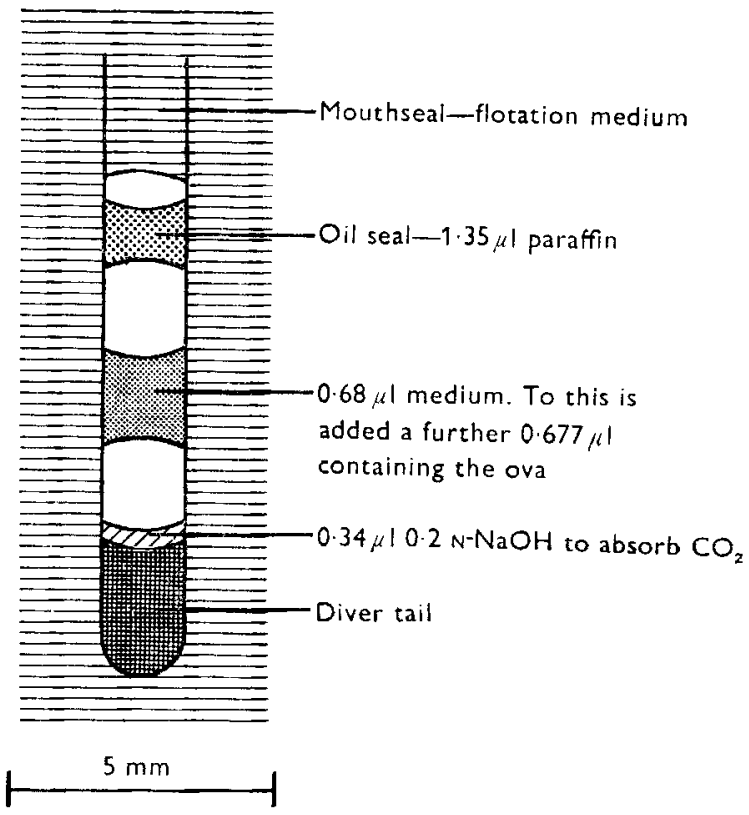

Fig. I. The Cartesian diver filled ready for measurement of oxygen uptake.

\section{Filling the diver}

The diver was filled by means of the fine calibrated micro-pipettes. The mouth seal was placed according to the respective 'diver constants'. By means of a wire hook, the diver was lowered into the flotation vessel supported in a bath at $37^{\circ} \pm 0.01^{\circ}$. All taps were greased well and closed.

In all experiments a control diver was included, which was filled in exactly the same way, but did not contain any ova. Thus it was a thermobarometer for the experiment. It was found necessary to include a control diver when working at $37^{\circ}$, as the air bottles did not always seem to compensate fully for atmospheric pressure changes. Small changes in the control diver were ignored, but whenever a large change occurred the pressure difference recorded with the experimental diver was considered unreliable. The time taken from the moment of killing the animal until manometric readings were commenced was generally about $2 \cdot 5-3 \cdot 5 \mathrm{~h}$.

After about Io min equilibration, readings of the manometer were commenced by means of a binocular eyepiece and graticule. This was done by adjusting the pressure so that the top of the diver remained immobile for at least Io sec. Readings were repeated several times until a constant pressure reading was obtained. As far as possible readings were taken at approximately Io min intervals over the first $2 \mathrm{~h}$, then, as the respiration rate became slower, less frequent readings were taken. 


\section{RESULTS}

Since most of the results, when plotted as mm pressure difference against time, showed a gradual decrease in rate, as in Fig. 2, this was considered to be the normal response of ova when subjected to the conditions within the divers. In a total of forty experiments, nine showed a similar curve for only $\mathrm{I}^{\cdot} 5^{-2} \mathrm{~h}$ and then fell off abruptly to almost zero; of these nine experiments, six were from animals reared on a diet of low protein value. It was thought probable that in these experiments the ova were more adversely affected by the experimental conditions. In addition to these forty experiments, there were eight in which no oxygen uptake could be detected. There was apparently no technical reason for this, and therefore these results should be considered as 'unexplained'. Six of the eight were for rats reared on the diet of low protein value.

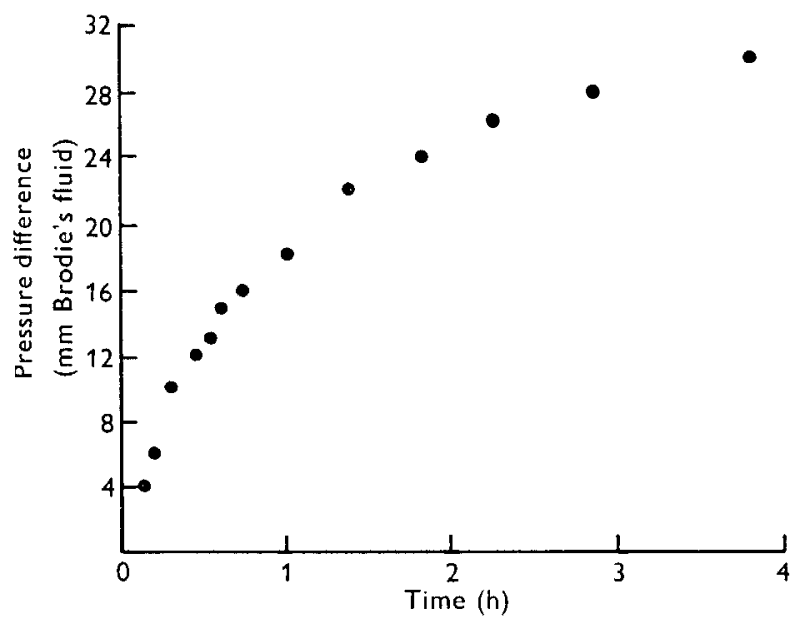

Fig. 2. Graph of oxygen consumption of fifteen rat eggs in the four-cell and eight-cell stages from two rats reared on a diet of protein value $\mathrm{NDpCal} \%$ I0. The medium used was $0.9 \% \mathrm{NaCl}$ $2:$ I rat plamsa.

In order to obtain a straight-line relationship, results were plotted as pressure differences against log time. Thus it was possible to calculate the average respiration rate

$$
\Delta_{v}=\frac{\Delta_{p}}{P_{0}}\left(V \cdot \frac{273}{310}\right),
$$

where $\Delta_{v}=$ change in volume, $P_{0}=10000 \mathrm{~mm}$ Brodie's solution, $\Delta_{p}=$ change in pressure (mm) and $V=$ diver constant.

Results of twenty-six experiments using media $C$ and $D$ were expressed as $m \mu l$ oxygen/ovum per $h$ and are presented in Table 2. Statistical analysis of the results showed that the difference between the two dietary groups was significant at $0.05>P$ $>0.02$. In these experiments for rats of similar mean weight in the two groups having dicts of high and low protein value respectively, the mean values obtained 
for the oxygen uptake of ova $\left(\mathrm{m} \mu \mathrm{l} \mathrm{O}_{2} /\right.$ ovum per $\left.\mathrm{h}\right)$ were $0.563 \pm 0.175$ and $0.440 \pm 0.076$.

Although most of the experiments were with two-cell ova, some results were obtained with four-cell, six-cell and eight-cell ova, but these were not higher than those from two-cell ova.

Table 2. Oxygen uptake of ova from rats fed on diets of high or low protein value

\begin{tabular}{|c|c|c|c|c|c|c|c|c|}
\hline \multirow[b]{2}{*}{$\begin{array}{l}\text { Medium } \\
\text { used* }\end{array}$} & \multicolumn{4}{|c|}{ NDpCal \% Io } & \multicolumn{4}{|c|}{ NopCal \% 5} \\
\hline & $\begin{array}{l}\text { No. of } \\
\text { eggs } \\
\text { per } \\
\text { diver }\end{array}$ & $\begin{array}{c}\text { Day of } \\
\text { pregnancy }\end{array}$ & $\begin{array}{l}\text { Stage: } \\
\text { no. of } \\
\text { cells }\end{array}$ & $\begin{array}{c}\mathrm{m} \mu \mathrm{l} \\
\mathrm{O}_{2} / \text { ovum } \\
\text { per } \mathrm{h}\end{array}$ & $\begin{array}{l}\text { No. of } \\
\text { eggs } \\
\text { per } \\
\text { diver }\end{array}$ & $\begin{array}{l}\text { Day of } \\
\text { pregnancy }\end{array}$ & $\begin{array}{l}\text { Stage: } \\
\text { no. of } \\
\text { cells }\end{array}$ & $\begin{array}{c}\mathrm{m} \mu \mathrm{I} \\
\mathrm{O}_{2} / \text { ovum } \\
\text { per } \mathrm{h}\end{array}$ \\
\hline $\mathrm{C}$ & $\begin{array}{l}7 \\
8\end{array}$ & $\begin{array}{l}2 \\
4\end{array}$ & ${ }_{4,6}^{2}$ & $\begin{array}{l}0.638 \\
0.548\end{array}$ & $\begin{array}{r}8 \\
8 \\
6 \\
6 \\
6 \\
14\end{array}$ & $\begin{array}{c}2 \\
2 \\
3 \\
3 \\
4 \\
2,3\end{array}$ & $\begin{array}{c}1,2 \\
2 \\
2 \\
2 \\
4 \\
1,2\end{array}$ & $\begin{array}{l}0.474 \\
0.554 \\
0.444 \\
0.582 \\
0.512 \\
0.372\end{array}$ \\
\hline D & 12 & 3 & 2 & 0.357 & $2 \mathrm{I}$ & 3 & 2 & 0.442 \\
\hline & I 5 & 4 & 4,8 & 0.586 & 14 & 3 & 2 & 0.323 \\
\hline & $\begin{array}{l}9 \\
8\end{array}$ & $\begin{array}{l}4 \\
3\end{array}$ & $\begin{array}{c}4,8 \\
2\end{array}$ & $\begin{array}{l}0.397 \\
0.765\end{array}$ & $\begin{array}{r}14 \\
9\end{array}$ & $\begin{array}{l}3 \\
2\end{array}$ & $\begin{array}{l}2 \\
2\end{array}$ & $\begin{array}{l}0.370 \\
0.465\end{array}$ \\
\hline & $\begin{array}{l}7 \\
6\end{array}$ & 2,3 & $\begin{array}{l}\mathrm{I}, 2,4 \\
2\end{array}$ & $\begin{array}{l}0.585 \\
0.635\end{array}$ & $\begin{array}{r}15 \\
7\end{array}$ & 2 & ${ }_{2}^{1,2}$ & $\begin{array}{l}0.392 \\
0.360\end{array}$ \\
\hline & 7 & 2,3 & $\mathbf{r}, 2$ & 0.675 & 12 & 2,3 & I, 2 & 0.522 \\
\hline & 4 & 4 & 8 & 0.788 & 13 & 3 & 2,4 & 0.387 \\
\hline & 10 & 3 & 2 & 0.217 & 7 & 2,3 & 1,2 & 0.404 \\
\hline $\begin{array}{l}\text { Mean } \\
\text { SD }\end{array}$ & & & & $\begin{array}{r}0.563 \\
\pm 0.175\end{array}$ & & & & $\begin{array}{r}0.440 \\
\pm 0.076\end{array}$ \\
\hline
\end{tabular}

NDpCal \% 10 $>$ NDpCal $\% 5$ at $0.05>P>0.02$.

* See Table 1 .

\section{DISCUSSION}

Oxygen uptake measured by the Cartesian diver was found to be $0.563 \pm 0.175 \mathrm{~m} \mu \mathrm{l}$ $\mathrm{O}_{2}$ /ovum per $\mathrm{h}$ for rats reared on a diet of $\mathrm{NDpCal} \% \mathrm{IO}$ and $0.440 \pm 0.076 \mathrm{m \mu l} \mathrm{O}_{2} /$ ovum per $\mathrm{h}$ for those reared on a diet of NDpCal $\% 5$ when measurements were made in medium containing $0.9 \% \mathrm{NaCl}$ and rat serum or plasma (2:1). The difference between these results may be an indication of some difference in the metabolic state of ova from rats reared on the two diets.

The range of values for oxygen uptake is about the same as, although the mean values are somewhat lower than, those found by Boell \& Nicholas (1948) and Sugawara \& Umezu (196r).

Perhaps a further indication of the inferior metabolic state of ova from rats reared on a diet of low protein value is the observation that, out of the total of forty experiments performed, only in nine of them did the respiration rate fall off rapidly, and six of these results were obtained from rats reared on the diet of low protein value. Also, in six out of eight 'unexplained' results, in which there was no measurable uptake of oxygen, the ova were obtained from rats reared on the diet of low protein value.

Extreme protein deficiency leads, in the female rat, to cessation of oestrus or to 
long and irregular oestrous cycles. The rats used in this experiment which were reared on a diet of NDpCal \% 5 apparently had cycles of normal length and mated within a day or two of co-habitation with a healthy male rat.

Bertók et al. (1962) found that a diet containing 6\% digestible protein of plant origin permitted rats to have oestrous cycles, but histological examination of the ovaries revealed the presence of degenerate ova. During oogenesis, both total nuclear protein (Alfert, 1950) and cytoplasmic protein (Flax, 1953) increase with cell growth. It is therefore suggested that in the present experiments some of the ova shed by the rats on the diet of low protein value were defective (as shown by diminished or failure of respiration) as a result of the harmful effect of a deficiency of protein during their development in the ovary.

It is generally assumed that the ovum, during its cleavage stages, draws nutritional reserves from its own cytoplasm, with a consequent progressive decrease in cell size and total cytoplasmic volume (Austin, I96I). However, Mintz (1964), using isotopically labelled leucine in the culture medium, has demonstrated that protein synthesis occurs in vitro in fertilized mouse eggs during their cleavage stages.

Total serum proteins of rats chronically malnourished with respect to protein were found to be lower than normal (Platt, Heard \& Stewart, 1964). In some experiments with rats of the same strain it has been found that animals fed on a diet of NDpCal \% ro had a total serum protein of $5.3 \mathrm{~g} / 100 \mathrm{ml}$ and animals fed on a diet of NDpCal $\% 5$ had a total serum protein of $4.7 \mathrm{~g} / 100 \mathrm{ml}$. Also, in experiments with older animals fed on the diets of NDpCal\% Io or NDpCal \% 5 at 21 days of pregnancy the mean value for the total serum protein of the blood of them other was $7.12 \mathrm{~g} / 100 \mathrm{ml}$ and for the foetal blood was $3.74 \mathrm{~g} / 100 \mathrm{ml}$ for the animals fed on the diet of higher protein value; for the animals fed on the diet of lower protein value the corresponding values were $5.70 \mathrm{~g} / 100 \mathrm{ml}$ and $2.66 \mathrm{~g} / 100 \mathrm{ml}$.

No effect of a dietary deficiency on the secretion of the oviduct has been reported. It seems possible that the animals reared on the diet of low protein value used in the present experiment may have had less protein in their tubal fluids than did the animals reared on the diet of high protein value. In the absence of ova, no differences in the $\mathrm{O}_{2}$ uptake of the media, whether they contained serum or plasma from animals on diets of high or low protein value, were detected (see p. 184).

The authors are grateful to all members of the Department of Human Nutrition for their interest in and help with this work, and especially to $\mathrm{Mr} \mathrm{P}$. R. Payne and his assistants for constructing the equipment, and to Miss S. Kriegsman for valuable technical assistance.

\section{REFERENCES}

Alfert, M. (1950). F. cell. comp. Physiol. 36, 381.

Asdell, S. A. \& Crowell, M. F. (1935). 7 . Nutr. Io, I3.

Austin, C. R. (196r). The Mammalian Egg. Oxford: Blackwell.

Bertók, L., Penzes, L. \& Szeky, A. (1962). Acta biol., hung. r2, Suppl. 4, p. 49.

Boell, E. J. \& Nicholas, J. S. (1948). F. exp. Zool. 109, 267.

Brinster, R. L. (1965). F. exp. Zool. r58,69.

Flax, M. H. (I953). Ribose nucleic acid and protein during oogenesis and early embryonic development in the mouse. Ph.D. Thesis, Columbia University. Quoted by Mintz, B. (1964). 
Gupta, S. R. \& Christie, B. (1968). Indian F. med. Res. 56, I I4.

Gupta, S. R. \& Lacy, B. (1967). Indian \%. med. Res. 55, 904.

Harper, M. J. K. (1964). Y. Reprod. Fert. 7, 185.

Hartman, C. G. (1953). In Mammalian Germ Cells, p. 253. [G. E. W. Wolstenholme, M. P. Cameron and J. S. Freeman, editors.] London: J. and A. Churchill.

Holter, H. (1943). C. r. Trav. Lab. Carlsberg. Sér. chim. 24, 399.

Holter, H. (1961). In General Cytochemical Methods. Vol. 2, p. 93. [J. F. Danielli, editor.] New York and London: Academic Press Inc.

Jones, J. H. \& Foster, C. (1942). F. Nutr. 24, 245.

Miller, D. S. \& Bender, A. E. (1955). Br. J. Nutr. 9, 382.

Mintz, B. (1964). F. exp. Zool. 157, 85.

Nelson, M. M. \& Evans, H. M. (1953). F. Nutr. 5r, 7 I.

Platt, B. S., Heard, C. R. C. \& Stewart, R. J. C. (1964). In Mammalian Protein Metabolism. Vol. 2, Ch. 2 I. [H. N. Munro and J. B. Allison, editors.] New York and London: Academic Press Inc.

Platt, B. S. \& Miller, D. S. (1959). Proc. Nutr. Soc. I8, vii.

Platt, B. S., Miller, D. S. \& Payne, P. R. (I96r). In Recent Advances in Human Nutrition, p. $35 \mathrm{I}$. [J. F. Brock, editor.] London: J. and A. Churchill.

Platt, B. S. \& Stewart, R. J. C. (1962.) Br. F. Nutr. 16, 483.

Schwartz, S. (1949). C. r. Trav. Lab. Carlsberg. Sér. chim. 27, 79.

Sugawara, S. \& Umezu, M. (1960). Tohoku Y. agric. Res. II, I 99.

Sugawara, S. \& Umezu, M. (196r). Tohoku F. agric. Res. 12, I7.

'Tempest, W. (1963). Electronic Engng 35, 814.

Waterlow, J. C. \& Borrow, A. (1949). C. r. Trav. Lab. Carlsberg. Sér. chim. 27, 93. 